\title{
COMPARISON STUDY ON TEACHERS' WORK MOTIVATION AT TAMAN PEMBACAAN ALQURAN (TPQ)
}

\author{
Fahmi Reza \\ Department of Psychology Islam IAIN Imam Bonjol Padang \\ email: rezafabmi125@gmail.com \\ Riyan Hidayat \\ Department of Psychology Islam IAIN Imam Bonjol Padang \\ email: riyanbidayat@gmail.com \\ DOI: http:/ / dx.doi.org/10.30983/islam_realitas.v3i1.210
}

\begin{tabular}{l|l|l} 
Diterima: 6 Mei 2017 & Direvisi : 29 Juli 2017 & Diterbitkan: 8 Agustus 2017
\end{tabular}

\begin{abstract}
The research was based on the fact that the TPQ teachers should receive incentives differently depend on their work motivation. The teachers who receive high incentives should also have high motivation to work compared those who receive lower incentives; TPQ teachers can raise the motivation in teaching and encourage the action towards a certain goal after getting encouragement in the form of incentive or certification. The purpose of this study was to describe the work motivation on TPQ teacher, TPQ teacher's certification, then to test whether any discrepancy of motivation between those who received incentives with $B$ and $C$ certificate in Kuranji, Padang. This study used a quantitative method with data analysis techniques by using two-independentsamples test which was processed with SPSS version 24.0 for Windows. A variable used in this research was the work motivation. The population in this study was 93 TPQ teachers who are located in Kuranji, Padang and 38 people were choosen to be the sample. The study used simple random sampling, the data were obtained by using psychological scale, which is based on the Likert scale model; this study used a scale as a measurement: motivation, and has a reliability of 0.740 . Based on the results of data analysis, it shows that the Independent Sample T-Test with tount $>t_{\text {table }}(0.688>0.05)$ then the bypothesis Ho is accepted, which is meant there is no discrepancy in work motivation among teachers who receive $B$ certification with those who receive $C$ certification in Kuranji District Padang.
\end{abstract}

Keywords: Motivation Training, Certification

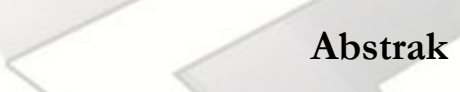

Penelitian ini didasarkan fakta bahwa seharusnya guru TPQ yang menerima insentif dengan jumlah yang berbeda memiliki motivasi kerja yang berbeda. Guru yang menerima insentif dengan jumlah yang lebih banyak seharusnya memiliki motivasi kerja yang lebih tinggi dibandingkan guru yang menerima insentif yang lebih rendah; guru TPQ dapat meningkatkan motivasi kerja dalam mengajar dan mendorong perbuatan ke arah suatu tujuan tertentu setelah mendapat dorongan berupa insentif atau sertifikasi guru TPQ yang diterima. Tujuan dari penelitian ini adalah untuk menjelaskan tentang motivasi kerja pada guru TPQ, sertifikasi guru TPQ, kemudian untuk menguji apakah ada atau tidaknya perbedaan motivasi kerja guru TPQ antara yang menerima insentif dengan sertifikasi B dan C di Kelurahan Kuranji Kecamatan Kuranji Kota Padang. Penelitian ini menggunakan metode kuantitatif dengan teknik analisis data yaitu analisis uji dua sampel independen (Two-Independent-Samples Test) yang diolah dengan program SPSS versi 24.0 for windows. Variabel yang digunakan dalam penelitian ini adalah motivasi kerja. Populasi dalam penelitian ini adalah guru TPQ yang berada di Kelurahan Kuranji Kecamatan Kuranji Kota Padang yang berjumlah 93 orang dan sampel penelitian berjumlah 38 orang. Penarikan sampel penelitian dengan menggunakansimple random sampling. Data diperoleh dengan menggunakan skala psikologi, yang berpedoman pada 
skala model Likert, penelitian ini menggunakan satu buah skala sebagai alat ukur yaitu skala motivasi kerja, dan memiliki reliabilitas 0,740 . Bedasarkan hasil analisis data penelitian menunjukan Independent Sample T-Test dengan thitung $>\mathrm{t}_{\text {tabel }}(0,688>0,05)$ maka hipotesis Ho diterima artinya tidak ada perbedaan motivasi kerja antara guru yang menerima sertifikasi B denga guru yang menerima sertfikasi $C$ di Kelurahan Kuranji Kecamatan Kuranji Kota Padang.

\section{Kata Kunci : Motivasi Kerja, Sertifikasi}

\section{Background}

This research is motivated by Table 1. TPQ Teacher Satisfaction Form in Kuranji Village the assumption that the TPQ teacher should receive different amount of incentives based on their motivation. The teachers who receive more incentives should have higher work motivation than teachers who receive lower incentives. The TPQ teacher can increase the motivation to teach and encourage action towards a certain goal after receiving the incentive from TPQ teacher certification.

The teachers who received the certification are categorized into 3 groups, based on the result of test conducted by the government: the welfare division of Padang. The groups are as follow: group A receives incentives for Rp.3,000,000, group B receives Rp. 2.100.000, and group $C$ received Rp. 1,200,000. The basic thing is that TPQ teachers who receive this certification should be more motivated in teaching although they receive different amount of in accordance with the ability of each teacher in the test. Therefore, every teacher must realize that the grade is in accordance with their competence.

Based on preliminary data that the researchers got by using questionnaires to TPQ teachers who received certification in Kuranji, there was a difference of satisfaction between the groups of teachers who receive different amount of incentive. It can be seen on the following table:

\begin{tabular}{|c|c|c|c|c|c|}
\hline No & $\begin{array}{l}\text { Certifi } \\
\text { cation }\end{array}$ & Amount & Satisfied & $\begin{array}{c}\text { Not } \\
\text { satisfied }\end{array}$ & Total \\
\hline 1 & $\mathrm{~A}$ & 7 people & 7 & - & 7 people \\
\hline 2 & B & 19 people & 19 & - & 19 people \\
\hline 3 & $\mathrm{C}$ & 65 people & - & 65 & 65 people \\
\hline & & Total & & & 91 \\
\hline
\end{tabular}

Based on the above table it can be seen that teachers who received the average $A$ certification were all satisfied with the incentives received, then the teacher who received the $\mathrm{B}$ certification were all satisfied, then the teacher who received the $\mathrm{C}$ certification was not satisfied on the amount of incentive.

However, incentive is not the main point, motivation of the TPQ teachers in teaching is more important. Motivation can encourage individuals to do their activity based on the goals that the want to achieve. A teacher is required to teach the learners sincerely and simply expect the pleasure of Allah SWT. It should motivate the teachers to teach at TPQ.

Furthermore, the significance of this study is to explain the work motivation on TPQ teacher, TPQ teacher certification, then to test whether any differences between the TPQ teacher's work motivation who receive incentives with $\mathrm{B}$ certification and C certification in Kuranji District of Padang. 


\section{Work Motivation Theory}

The term motivation comes from the Latin word "movere"1 which means a push or move. Motivation questions how to direct the power and potential to work to achieve the goals set $^{2}$. Basically, one works to fulfill the needs of his life. The urge of desire in each person are different so that human behavior tends to vary in working. According to Vroom $^{3}$, motivation refers to a process of influencing individual choices of the various forms of activity they desired. Then John P. Campbell, et al. suggested that motivation includes the direction or purpose of behavior, the power of response, and the persistence of behavior. In addition, the term covers a number of concepts of drive, necessity, incentive, reward, reinforcement, goal setting, expectancy, and so on.

According to Hamzah B. Uno, work is as 1) a basic activity and an essential part of human life, 2) work provides status, and binds one person to another individual and society, 3) in general, women or men like to work, 4) the morale of workers and employees have no direct connection with the physical and material conditions of the works, 5) work incentive has many forms, money is one of them $^{4}$. Motivation of work is a motivation that occurs in the situation and work environment in an organization or institution. The success and failure of education is often associated with teachers' work motivation. Basically,

\footnotetext{
${ }^{1}$ Atkinson, RL., Introduction to Psychology (New York: Mc Grew Hill, 2010), h. 34.

${ }^{2}$ Munandar, Asr Sunyoto, Psikologi Industri dan Organisasi (Jakarta: Universitas Indonesia, 2008), 43.

${ }^{3}$ Atkinson, RL, Introduction to Psycholog....., h. 20.

${ }^{4}$ Wijono, S., Psikologi Organisasi dan Industri (Jakarta: RajaGrafindo, 2015), h.63
}

people always want good things, so the driving force or motivator who motivates the spirit of work will depend on the hope in the future: if the hope comes true, someone will tend to increase the work motivation ${ }^{5}$.

According to Ngalim Purwanto, motivation contains three main components, namely: 1) moving: arise the power on the individual, leading a person to act in a certain way, 2) direct or channel the behavior. Thus, it provides a goal orientation. Individual behavior is directed toward something. 3) In order to maintain or sustain the behavior, the environment must reiforce the intensity, drives and individual power. ${ }^{\circ}$ Based on several definitions and basic components above, it can be formulated that motivation is the impetus or power that generates and directs the behavior of an action or work.

The types of motivation can be grouped into two types according to Malayu S. P Hasibuan, namely: 1) Positive motivation (positive incentives): a manager motivates his staffs by giving gifts to those who have good achievements. With this positive motivation, the staffs' work spirit will raise because humans are generally happy to accept the good things, 2) Negative motivation (negative incentives): a manager motivates the staffs by giving punishment to those who have low achievement in working ${ }^{7}$. By the negative motivation, the morale of the staff will raise shortly, for fear of punishment. The use of

${ }^{5}$ Anthony, Glenda, and Kate Ord, "Change-of-Career Secondary Teachers: Motivations, Expectations and Intentions", Asia-Pacific Journal of Teacher Education, 36.4, 2008, h. 359-376.

${ }^{6}$ Ngalim Purwanto, Psikologi Pendidikan (Jakarta: Gramedia, 2014), h. 32.

${ }^{7}$ Malay S. P Hasibuan, Pengantar Organisasi. (Jakarta: Gramedia, 2013), h. 40 
these two motivations should be applied to anyone, anywhere in order to stimulate the passion of the staffs in working ${ }^{8}$.

Staff behavior in an organization, such as schools is essentially task-oriented: that is, the behavior of staffs are usually driven by the desire to achieve goals; it should always be observed, supervised, and directed in achieving organizational goals that have been established. In general, the purpose of motivation is to move or arouse a person to arise the desire and willingness to do something to obtain results or achieve certain goals ${ }^{9}$. Moreover, the purpose of motivation in Malayu S.P. Hasibuan revealed that: 1) Improve the employee's morale and job satisfaction. 2) Increase the employee's work productivity. 3) Maintain the stability of company's employees. 4) Increase the discipline of employees' attendance 5) Have an effective employees' procurement. 6) Create a good atmosphere and work relationship. 7) Increase loyalty, creativity and employees' participation. 8) Improve employees' welfare level. 9) Enhance employees' sense of responsibility towards their duties. 10) Improve the efficiency of the use of tools and raw materials ${ }^{10}$.

Motivational action will be more successful if the objectives are clear and awared and fit the needs of the motivated person. Therefore, every person who will motivate must know and understand the true

${ }^{8} \mathrm{Hamdu}$, Ghullam, and Lisa Agustina, "Pengaruh Motivasi Belajar Siswa terhadap Prestasi Belajar IPA di Sekolah Dasar", Jurnal Penelitian Pendidikan, 12.1, 2011, h. $90-96$.

${ }^{9}$ Ngalim Purwanto, Psikologi Pendidikan..., h.32

10 Malay S. P Hasibuan, Pengantar Psikologi...., h. 123

Fahmi Reza E Riyan Hidayat background of life, needs, and personality of the person who will be motivated ${ }^{11}$.

According to Sardiman there are three functions of motivation: 1) To encourage people to do: this motivation is the motor of any activities to be undertaken. 2) Determine the direction of action, that is toward the goal to be achieved, so that motivation can provide direction and activities to be done in accordance with the formulation of its purpose. 3) Select the act, that is determines what actions should be done accordingly in order to achieve the goal, by setting aside the actions that are not beneficial to that goal ${ }^{12}$.

$\begin{array}{clcc}\text { Meanwhile, } & \text { Malayu S. P }\end{array}$
motivation, namely: 1) Direct Motivation. It is a motivation (material and nonmateriil) given directly to each individual to meet their needs and satisfaction. So, it is special, such as praise, appreciation, holiday allowance, and so forth. 2) Indirect Motivation. This motivation is provided by giving the facilities that support the spirit of work, in order to raise the spirit of the staff in working. For example, good machines, comfortable workspaces, soft chairs, and so on ${ }^{13}$.

Furthermore, the theory of motivation according to Malaya S.P. Hasibuan is divided into two groups, namely: The theory of satisfaction (Content Theory). This theory is based on needs factors and individual satisfaction which led to act and behave in a

${ }^{11}$ Harun, Halimah. "Minat, Motivasi Dan Kemahiran Mengajar Guru Pelatih", Jurnal Pendidikan Malaysia (Malaysian Journal of Education), 31, 2006, h. 8396.

12Sardiman, Psikologi Umum (Jakarta: Raja Grafindo, 2010), h. 21.

${ }^{13}$ Malay S. P Hasibuan, Pengantar Psikologi ......, h. 76 
certain way ${ }^{14}$. This theory focuses on factors in the person which strengthens, directs, supports and stops his behavior. If the needs are fulfilled, then the spirit of the work will be much better ${ }^{15}$.

These satisfaction theories include: a) Classical Motivation Theory. This single needs motivation theory is suggested by F.W Taylor. This theory argues that humans want to work hard to be able to meet the physical needs in the form of money or goods from the work ${ }^{16}$. The basic concept of this theory is that people will work diligently when they receive material rewards related to their tasks. b) Maslow's Theory. Maslow's Hierarchy of needs follows the plural theory, that is people behave or work, for their urge to meet a variety of needs. Maslow argues the needs of human beings are tiered $^{17}$. Maslow puts forward five levels of needs, as follows: (1) Physiological needs: it is the needs that must be satisfied in order to survive, including food, housing, clothing, air to breathe, and so on. (2) The needs for safety and security: it is the needs for freedom from the threat feeling, that is safe from the threat of accidents and safety in carrying out the work. (3) Social needs: it is the needs of friends, interaction, loved, and loving, and accepted within the workers group association 32

${ }^{14}$ Malay S. P Hasibuan, Pengantar Psikologi ...... h.

15 Harvey, Pamela, Catherine Sinclair, and Martin Dowson, "Teacher Motivations for Postgraduate Study: Development of A Psychometric Scale for Christian Higher Education", Christian Higher Education, 4.4, 2005, h. 241-264

16 Atkinson,. Introduction to Psychology......, h.54

${ }^{17}$ Irwanto, Psikologi Umum (Jakarta: Prenhalindo, 2016), h. 43. Watt, Helen MG, and Paul W. Richardson, "Motivations, Perceptions, and Aspirations Concerning Teaching as a Career for Different Types of Beginning Teachers", Learning and Instruction, 18.5, 2008, h. 408428.

Fahmi Reza E Riyan Hidayat and environmental community. (4) The need for esteem: it is the needs of recognition and self-esteem of the employees and environmental community. (5) Selfactualization: It is the needs of self actualization by using ability, skills, and the optimal potential for achieving satisfying or extraordinary work performance.

c) Herzberg's Theory. According to Hezberg, people want two kinds of needs. (1) The needs for health or needs of maintenance (maintenance factors). Health factors is a continuous needs, because this requirement will return at zero after fulfilled. Maintenance factors include remuneration, conditions of physical labor, supervision, and various benefits. (2) Maintenance factors concerning the Psychological needs. This needs includes a series intrinsic conditions, job satisfaction which drives the strong motivation which can produce good performance ${ }^{18}$.

d) Theory $\mathrm{X}$ and Theory $\mathrm{Y}$ of Mc. Gregor. According to theory $\mathrm{X}$, a manager should do a close supervision, forced, and direction to work hard in order to motivate the employee. It refers to the negative motivation, that is by applying strict punishment. Mean while, according to theory $\mathrm{Y}$, to motivate the employees should be done by increasing the participation, cooperation, and attachment to decision. e) Mc Clelland's theory. This theory argues that employees have potential energy reserves. How the energy is released and used will be depending on the strength, drive,

${ }^{18}$ Wijono, S., Psikologi Organisasi dan Industri (Jakarta: RajaGrafindo, 2015), h. 76. Werdayanti, Andaru, "Pengaruh Kompetensi Guru dalam Proses Belajar Mengajar di Kelas dan Fasilitas Guru Terhadap Motivasi Belajar Siswa", Dinamika Pendidikan, 3.1, 2008, h. 23. 
motivation of a person and the available situations and opportunities ${ }^{19}$. Energy will be exploited by employees because it is driven by:

(1) The needs for a motive and basic forces involved. (2) Expectations of success. (3) The value of the incentives attached to the destination. The things that motivate a person are: (1) The needs for achievement. (2) The needs for affiliation. (3) The need for dignitsy.

(f) Claude S. George's Motivation Theory. This theory suggests that a person has needs which is related to place and atmosphere at the work environment, namely: (1) Fair wages and decent. (2) The opportunity to move forward. (3) Recognition as an individual. (4) Job security. (5) A good place to work. (6) Acceptance by the group. (7) The treatment is reasonable. (8) Recognition of the achievement $^{20}$.

Motivation is a psychological process within a person and strongly influenced by various factors ${ }^{21}$. In general, this factor can arise from inside (intrinsic) as well as from outside the self (Extrinsic). According to Wahjosumidjo, factor influences motivation include internal factors that are sourced from inside the individual and external factors that come from outside individual. Internal factors such as attitudes toward work, talent, interests, satisfaction, experience, etc. and external

${ }^{19}$ Wijono, S., Pengantar Psikologi ....., h. 43. Van Duzor, Andrea Gay, "Capitalizing on Teacher Expertise: Motivations for Contemplating Transfer from Professional Development to the Classroom", Journal of Science Education and Technology, 20.4, 2011, h. 363-374.

${ }^{20}$ Wilson, Manajemen Sumber Manusia (Jakarta: Erland, 2012), h. 54. 2016), h. 46 factors concerned to supervision, salary, work environment, and leadership ${ }^{22}$.

Meanwhile, according to Sondang P. Siagan motivation is influenced by several factors, both internal and external. The internal factors are: 1) Perception of someone about himselfself. 2) Self-esteem. 3) Personal expectations. 4) Needs. 5) Desire. 6) Job satisfaction. 7) Work achievement. Meanwhile, the external factors that influences someone motivation includes: 1) The type and nature of work. 2) The working group in which one is joined. 3) Organization where the people work. 4) The situation of the working environment. 5) Salary ${ }^{23}$.

In relation to the factors influence motivation in the work environment is the leader and staff. Here are some factors from the leader side which affect the motivation, such as: 1) The established policies, including work procedures, work plans, and work programs. 2) Working requirements that need to be met by the staff. 3) Availability of a set of required tools to support the implementation of work, including how the staffs work. 4) Leadership style of the leader. On the other hand, in giving motivation the staffs have the symptoms characteristic such as: 1) The ability to work. 2) Spirit to work. 3) Sense of unity in the life of the group. 4) Performance and productivity.

Meanwhile, according to Hamzah B.Uno the person who have a working motivation will be visible through: 1) Responsibility in doing work, including: a)

22 Hidayat, H. Sholeh, "Hubungan Minat terhadap Profesi Guru dan Motivasi Berprestasi dengan Keterampilan Mengajar", Jurnal Pendidikan dan Kebudayaan, 14.75, 2016, h. 1140-1154

${ }^{23}$ Wilson, Manajemen Sumber Daya Manusia h. 41. 
Work hard. b) Responsibility. c) The achievement of the goal. d) Unity with the task. 2) Achievements, including: a) The drive to succeed. b) Feedback. c) Superior. 3) Selfdevelopment, including: a) Increasing skills. b) Driving for progress. 4) Independence in acting, including: a) Independent work. b) Likes the challenge ${ }^{24}$. Based on some basic theories above, it can be formulated that work motivation is the driving force or power whick awake and direct behavior on an action or work on real efforts to achieve goals that have been set. Implicitly, work motivation appears through: a. Responsibility in doing the work. b. Achievements. c. Self-development, as well as d. Independence in acting

\section{Job Satisfaction}

According to Malayu Hasibuan, work is a number of physical and mental activity carried out by someone to do a job. Meanwhile, according to Osborn "work is an activity that produces a value for others" ${ }^{25}$.

When an individual works in an organization, agency or company then the work that he completed will affect the level of organizational productivity. Therefore, the views and also the feelings of individuals on their work must remain awake on the positive side of his work. In other words, the individual must have and keep the job satisfaction so that productivity can continue ${ }^{26}$. The following are

53.

${ }^{24}$ Wijono, S., Psikologi Organisasi dan Industri....., h.

${ }^{25}$ Wilson, Manajemen Sumber Daya Manusia..., h.31. Manuel, Jackie, and John Hughes, "It Has Always Been My Dream': Exploring Pre-Service Teachers' Motivations for Choosing to Teach", Teacher Development, 10.1, 2006, h. 5-24.

26 Hildebrandt, Susan A., and Minhee Eom, "Teacher Professionalization: Motivational Factors and definitions of job satisfaction according to experts: Marihot Tua Efendi says that job satisfaction is defined into how far the individuals feel various the factors or dimensions of the tasks positively or negatively ${ }^{27}$. Stephen Robbins suggests that the term satisfaction refers to the general attitude of an individual towards his work ${ }^{28}$. A person with a high level of job satisfaction indicates a positive attitude toward the work; someone who is not satisfied with his work shows a negative attitude to the job, because in general, if a leader talks about employees, it is going to be related to the job satisfaction. Furthermore, according to Malayu SP Hasibuan, job satisfaction is a pleasant emotional attitude and loves his job. This attitude is reflected by work morale ${ }^{29}$, discipline, and work performance. Job satisfaction is enjoyed in work, out of work, and in combination between the two. Veithzal Rivai tells that job satisfaction is an evaluation which describes someone on feeling happy or not happy in their work attitude ${ }^{30}$. Meanwhile, according to Cherington "Job satisfaction basically refers to how much an employee likes his job"31.

Work is an important part of a person's life, so job satisfaction also affects a person's

the Influence of Age", Teaching Teacher Education, 27.2, 2011, h. 416-423. 32 ${ }^{27}$ Wijono, S., Psikologi Organisasi dan Industri ..., h.

${ }^{28}$ Wijono, S. Psikologi Organisasi dan Industri ..., h. 35. Ryan, Richard M., and Edward L. Deci, "Intrinsic and Extrinsic Motivations: Classic Definitions and New Directions", Contemporary Educational Psychology, 25.1, 2000, h. 54-67

${ }^{29}$ Malay S. P Hasibuan, Pengantar Psikologi.., h. 54. ${ }^{30}$ Wijono, Psikologi Organisasi dan Industri ..., h. 53. ${ }^{31}$ Wilson, Manajemen Sumber Daya Manusia ..... h. 43 
life, that is why job satisfaction is part of life satisfaction. Job satisfaction also depends on the intrinsic, extrinsic, and worker perceptions of the work, so job satisfaction is the level at which a person feels positive or negative about various aspects of works, work place, and relationships with co-workers ${ }^{32}$. Gibson Ivanicevic Donely, stated that job satisfaction basically is something that is individual ${ }^{33}$. Every individuals have varies level of satisfaction based on the value system act on him. The higher the assessment of the activity is felt in accordance with the wishes of the individual, the higher the satisfaction of the activity. Hence, generally job satisfaction can be interpreted as a fun or unpleasant thing, depend on how the employees see his job. According to Herzberg as quoted by Suryana Sumantri, the characteristics of satisfied workers are those who have high motivation to work, they are happy in their work, while the characteristics of unhappy workers are those who are lazy to go to work, and lazy in doing their activity to work $^{34}$. Thus, it can be concluded that job satisfaction is a feeling or attitude of someone in their work, which can be influenced by various factors, both internal factors and external factors.

Job satisfaction is how people feel the job and its aspects. There are several reasons why companies should really pay attention to job satisfaction, which can be categorized

32 Karweti, Engkay, "Pengaruh Kemampuan Manajerial Kepala Sekolah dan Faktor Yang Mempengaruhi Motivasi Kerja terhadap Kinerja Guru SLB di Kabupaten Subang", Jurnal Penelitian Pendidikan, 11.2, 2010, h. 77-89

43.

${ }^{33}$ Wilson, Manajemen Sumber Daya Manusia ..... h. h..43.

${ }^{34}$ Wilson, Manajemen Sumber Daya Manusia ....,

Fahmi Reza \& Riyan Hidayat according to the company or focus to the employee: 1. Human beings are entitled to be treated with justice and respect: this view is based on the perspective of humanity. Job satisfaction is an expansion of good behavior. It is also important to pay attention to emotional indicators or psychological health. 2 . Perspectives of usefulness, that job satisfaction can create behaviors that affect corporate functions.

According to Stephen Robbins, there are two approaches to measure the employees satisfaction, namely: (1) Single global rating. This method asks the individuals to answer a single question, such as the one "When all things are considered, how satisfied are you with your job?". Then the respondents answer by circling an intermediate number $1-5$ by answering from "Very Satisfied" to "Very Unsatisfied". (2) Summation Score. This method identifies the main elements in a job and asks employees' feelings about each element $^{35}$. The common factors are the nature of work, supervision, current wages, promotional opportunities, and relationships with co-workers. These factors are assessed on raw scale and then totalized to create the whole of job satisfaction scores.

Furthermore, Theory of Work Adjustment measures 20 dimensions which explain 20 elements or needs condition in creating job satisfaction. The dimensions are described as follows: a. Ability Utilization is the use of skills owned by employees. b. Achievement is an accomplishment achieved during work. c. Activity is any kind of activity done in work. $\mathrm{d}$. Advancement is the progress or development

${ }^{35}$ Wilson, Manajemen Sumber Daya Manusia ...., h. 43 
achieved during the work. e. Authority is the authority which is possessed in doing the work. f. Company Policies and Practices is a fair policy for employees. g. Compensation is any form of compensation granted to employees. h. Co-workers are co-workers who are directly involved in the work. i. Creativity is a creativity that can be done in doing the job. $j$. Independence is the independence of employees in the work. k. Moral values are the moral value of employees in doing their work like guilt/forced. 1. Recognition is the recognition of the work done. $\mathrm{m}$. Responsibility is responsibilities carried and owned. n. Security is the sense of security that employees feel about their work environment. o. Social Service is the social feeling of employees to their work environment. p. Social Status is the degree of social and self-esteem that is felt as a result of work. q. SupervisionHuman Relations is the support given by the enterprise to its workers. r. SupervisionTechnical is the guidance and technical assistance provided by employers to employees. s. Variety is a variation that employees can do in their work. t. Working Conditions is the state of the workplace where employees do their work ${ }^{36}$.

The impact of job satisfaction and dissatisfaction, among others; 1 . Performance. Lawler and Porter expect high productivity led to an increase of job satisfaction; 2. Absence and Turn Over. Porter \& Steers said that absenteeism and stop working is the kind of

\footnotetext{
${ }^{36}$ Wijono, Psikologi Organisasi dan Industri ..., h. 53. Lizzio, Alf, Neil Dempster, and Regan Neumann, "Pathways to Formal and Informal Student Leadership: The Influence of Peer and Teacher-Student Relationships and Level of School Identification on Students' Motivations", International Journal of Leadership in Education, 14.1, 2011, h. 85-102.
}

answer that qualitatively different. Absence is more of a spontaneous and thus less likely reflect the job dissatisfaction; however, stop working or out of work is more likely relate to work disloyalty. Robbins stated that work dissatisfaction on the workforce or employees can be expressed in a variety of ways. For example, in addition to leave the job, the employees can complain, defy, steal the belongings of the organization, avoid some of the work responsibility ${ }^{37}$.

Factors that affect job satisfaction according to Hasibuan are as follows: a. A fair and reasonable reward; b. An appropriate Job placement; c. Severity of work. d. Atmosphere and work environment. e. The equipments support the implementation of work. $f$. The attitude of the leader in the leadership. g. The monotonous or non-monotonous work ${ }^{38}$.

Based on research conducted by Robinson and Corners, it is estimated not less than 3,350 pieces of articles related to job satisfaction: mentions that job satisfaction will provides benefits, as follows: a) Increase the happiness of employees life; b) Increase the productivity and work achievement; c) Cost reduction through attitude improvement and employee behavior; d) Increase passion and work spirit; e) Reduce absenteeism; f) Reduce labor turn over; g) Reduce accident rate; $h$ ) Reduce work safety; i) Increase work motivation; j) Cause psychological maturity; and, k)Positive attitude towards his work ${ }^{39}$.

53 43 43.
37 Wilson, Manajemen Sumber Daya Manusia ...., h.

38 Wilson, Manajemen Sumber Daya Manusia ...., h.

${ }^{39}$ Wilson, Manajemen Sumber Daya Manusia ...., h. 


\section{Methods}

This research is a field research which describe a condition or event ${ }^{40}$. The method that the writer uses is quantitative research method that is scientific method that has fulfilled the concrete/empirical scientific norms, objective, measurable, rational, and systematic. The data from this quantitative research method are numerical and statistical analysis ${ }^{41}$. In this study, the researchers used a comparative study that intends to compare the existing conditions in two places, whether the conditions are the same, or there are differences, and if there is a difference, the conditions in which place is better.

\section{Results And Discussion}

Based on various statistical analyzes used in this study were found as follows:

Table 2. Test Normality of Distribution Scale of Work Motivation

\begin{tabular}{|c|c|c|c|}
\hline \multicolumn{4}{|c|}{ One-Sample Kolmogorov-Smirnov Test } \\
\hline & & B & $\mathrm{C}$ \\
\hline \multicolumn{2}{|l|}{$\mathrm{N}$} & 19 & 19 \\
\hline \multirow{2}{*}{$\begin{array}{l}\text { Normal } \\
\text { Parameters a,b }\end{array}$} & Mean & 81.68 & 80.68 \\
\hline & $\begin{array}{l}\text { Std. } \\
\text { Deviation }\end{array}$ & 7,638 & 7,602 \\
\hline \multirow{3}{*}{$\begin{array}{l}\text { Most Extreme } \\
\text { Differences }\end{array}$} & Absolute &, 111 &, 156 \\
\hline & Positive &, 111 &, 087 \\
\hline & Negative &,- 094 &,- 156 \\
\hline \multicolumn{2}{|l|}{ Test Statistic } &, 111 &, 156 \\
\hline \multicolumn{2}{|c|}{ Asymp. Sig. (2-tailed) } & $200 \mathrm{c}, \mathrm{d}$ & $200 \mathrm{c}$ \\
\hline \multicolumn{4}{|c|}{ A. Test distribution is Normal. } \\
\hline \multicolumn{4}{|c|}{ B. Calculated from data. } \\
\hline \multicolumn{4}{|c|}{ C. Lilliefors Significance Correction. } \\
\hline
\end{tabular}

${ }^{40}$ Anwar, Saifuddin, Manajemen Sumber Daya Manusia (Yogyakarta: Pustaka Student, 2009), h. 85. h. 65 .

${ }^{41}$ Azwar, Saifuddin, Penyusunan Skala Psikologi...,
In order to know the normality of distributed data, we can see the table OneSample Kolmogorov-Smirnov Test above. The test criteria is when the significance value is $>$ 0.05 then the data is normally distributed. From the table above, we can know that the value of significance (asymptotic Significance 2tailed) for work motivation is 0.200 . Significance for variables in greater than 0.05 then it is normally distributed. So we can conclude that the scale of work motivation is normal distribution.

\section{Homogeneity Test}

Homogeneity test is used as a prerequisite test to do free samples $\mathrm{t}$ test (Independent sample $T$ test) and test variants of one course (One Way Anova). This test is to determine whether some variants of the data population is the same or not. If the significance of more than 0.05 then it can be said that the variant of two or more factors of the data group is the same, the following is the table of homogeneity test:

Table 3. Homogeneity Test Result

\begin{tabular}{lccc}
\hline \multicolumn{3}{c}{$\begin{array}{c}\text { Test of Homogeneity of Variances } \\
\text { Motivation }\end{array}$} & \\
\hline $\begin{array}{l}\text { Levene } \\
\text { Statistic }\end{array}$ & Df1 & Df2 & Sig. \\
\hline ,341 & 1 & 36 &, 563 \\
\hline \multicolumn{2}{l}{ Source: SPSS 24.0 } & & \\
\hline
\end{tabular}

Based on table above, it can be seen that the significance value is 0.563 . Due to the great significance of 0.05 , it can be concluded that the variant of the two group of data: certified $B$ and $C$ are the same, or variation of the same 
value is also called homogeneous, then it has met the basic assumptions.

\section{Hypothesis testing}

T-Test/Independent Samples Test or different second test average was used to test two averages in two independent data sets.

Table 4. Hypothesis

\begin{tabular}{lcccccc}
\hline \multicolumn{5}{c}{ Group Statistics } \\
\hline $\begin{array}{l}\text { the grade of } \\
\text { certification }\end{array}$ & & & & & $\begin{array}{c}\text { Std. } \\
\text { Std. }\end{array}$ & $\begin{array}{c}\text { Error } \\
\text { Mean }\end{array}$ \\
\hline $\begin{array}{l}\text { the number of } \\
\text { grade }\end{array}$ & $\mathrm{B}$ & 19 & 81.68 & 7.638 & 1,752 \\
\cline { 2 - 7 } & $\mathrm{C}$ & 19 & 80.68 & & 7.602 & 1,744 \\
\hline Source: SPSS 24.0 & & & & &
\end{tabular}

The number of teachers who get $\mathrm{B}$ certification is 19 teachers, while C certification is also 19 teachers. On average motivation for B certification is 81.68 while $\mathrm{C}$ is 80.68. The standard deviation is the motivation for certification B is 7.638 , while C is 7.602. The standard error of the mean motivation for certification B is 1,752 whereas $\mathrm{C}$ is 1,744 .

Two different test average (Independent Samples T Test) is used to determine whether there are differences in motivation among teachers who receive $\mathrm{B}$ certification with teachers who receive $\mathrm{C}$ certification. The test is using a significance level of 0.05 . Before the average of two different test is performed, $\mathrm{F}$ test needs to be done first. If the variant is similar, the t test uses Equal Variance Assumed (assumed to be the same variant) and if it is different, it uses Equal Variance Not Assumed (assumed different variants).

In determining the $\mathrm{F}$ test, hypothesis should be specified: Ho is accepted if the group data of work motivation between $\mathrm{B}$ and C certification have the same variant, Ho is rejected if the data group of work motivation between those who get $\mathrm{B}$ and $\mathrm{C}$ certification have different variants. The significance of the test $F$ can be 0.563 . Due to the significance value greater than 0.05 then $\mathrm{Ho}$ is accepted. So, it can be concluded that the motivation of the data group between $\mathrm{B}$ and $\mathrm{C}$ certified have the same variance (Equal Variance Assumed).

From the table above it is known that $\mathrm{t}$ count is 0.404 while $t$ table can be seen in the 0.05: $2=0.05$, with degrees of freedom $(\mathrm{df}) \mathrm{n}$ 2 or $38-2=36$. The results obtained for $t$ table is -2.028. It can be concluded that $t$ table is smaller than $t$, then Ho is accepted. Based on the significance of .688 that is greater than 0.05; then Ho is also acceptable. Therefore, it can be conclude that there is no difference in employee motivation among teachers who receive $\mathrm{B}$ and $\mathrm{C}$ certification in Kuranji village..

\section{Discussion}

Based on the results of data analysis by using Independent Samples T Test, it is shown that there is no significant differences in work motivation among teachers who receive $B$ certification with teachers who receive $\mathrm{C}$ certification in Kuranji District of Padang. At the T-Test, it is obtained that $\mathrm{t}$ count $=0.404$ and $\mathrm{t}$ table $=-2.028(-2.028 \geq 0.404)$, then $\mathrm{Ho}$ is accepted. It means there is no significant difference between the TPQ teachers' work motivation who receive $B$ certification with teachers who receive $\mathrm{C}$ certification in Kuranji District of the city of Padang,

There is no difference of work motivation between teacher with $\mathrm{B}$ certification and $\mathrm{C}$ certification. Although the teachers who receive $\mathrm{C}$ certification earn smaller number of incentive than the teachers who receive $\mathrm{B}$ certification, it does not 
distinguish the level of their work motivation. This is proven from the research findings that there is no significant difference between the teachers who receive $B$ certification with teachers who receive $\mathrm{C}$ certification.

Work motivation possessed by teachers who certified B with a certified teacher in the Village Kuranji C Kuranji Padang District of the same, this could have been caused by factors that affect the work motivation itself. According to Hezberg in Wilson, there are two things that affect one's motivation in the work that is intrinsic and extrinsic factors ${ }^{42}$.

Intrinsic factor is a reward from within that one feels when doing the work, so there is a direct link between work and reward employees motivated in this situation alone. While extrinsic factor is the factor from outside of work, which does not cause satisfaction conducted, such as a pension planning, health insurance, and vacation ${ }^{43}$.

\section{Conclusion}

Based on the results of research and discussion, it can be said that there is no significant differences in work motivation among teachers who receive $\mathrm{B}$ certification with teachers who receive $\mathrm{C}$ certification. It means that the salary or income is not the only measure to see the work motivation of teachers. Then, the dedication shown by teachers are relatively good, which means that the teachers are not oriented to the material aspects only. Furthermore, the loyalty shown by teachers also give a good overview: they h. 319

42 Wilson, Manajemen Sumber Daya Manusia ......,

43 König, Johannes, and Martin Rothland, "Motivations for Choosing Teaching as a Career: Effects on General Pedagogical Knowledge during Initial Teacher Education", Asia-Pacific Journal of Teacher Education, 40.3, 2012, h. 289-315 appreciate and love their job, so they do not measure their job satisfaction on a purely financial aspects. Moreover, they are sincere in doing their role as educators as they understand that their performance is expected as the charity for the hereafter life. Therefore, it is worth noting that many factors affect the work motivation; not only incentives or certification. It also proves that other studies still need a deeper understanding of performance the teachers issues that would be expected able to improve the learning quality in the field of religion, especially Islamic education.

\section{References}

\section{Text Books}

Atkinson, RL., Introduction to Psychology (New York: Mc Grew Hill, 2010).

Munandar, Asr Sunyoto, Psikologi Industri dan Organisasi (Jakarta: Universitas Indonesia, 2008).

Wijono, S., Psikologi Organisasi dan Industri (Jakarta: RajaGrafindo, 2015).

Ngalim Purwanto, Psikologi Pendidikan (Jakarta: Gramedia, 2014).

Malay S. P Hasibuan, Pengantar Organisasi. (Jakarta: Gramedia, 2013).

Sardiman, Psikologi Umum (Jakarta: Raja Grafindo, 2010).

Irwanto, Psikologi Umum (Jakarta: Prenhalindo, 2016)

Wijono, S., Psikologi Organisasi dan Industri (Jakarta: RajaGrafindo, 2015).

Wilson, Manajemen Sumber Manusia (Jakarta: Erland, 2012).

Irwanto, Psikologi Umum (Jakarta: Prenhalindo, 2016). 
Anwar, Saifuddin, Manajemen Sumber Daya Manusia (Yogyakarta: Pustaka Student, 2009).

\section{Journals}

Anthony, Glenda, and Kate Ord, "Change-of-Career Secondary Teachers: Motivations, Expectations and Intentions", Asia-Pacific Journal of Teacher Education, 36.4, 2008.

Hamdu, Ghullam, and Lisa Agustina, "Pengaruh Motivasi Belajar Siswa terhadap Prestasi Belajar IPA di Sekolah Dasar", Jurnal Penelitian Pendidikan, 12.1, 2011.

Harun, Halimah. "Minat, Motivasi Dan Kemahiran Mengajar Guru Pelatih", Jurnal Pendidikan Malaysia (Malaysian Journal of Education), 31, 2006.

Harvey, Pamela, Catherine Sinclair, and Martin Dowson, "Teacher Motivations for Postgraduate Study: Development of A Psychometric Scale for Christian Higher Education", Christian Higher Education, 4.4, 2005.

Hidayat, H. Sholeh, "Hubungan Minat terhadap Profesi Guru dan Motivasi Berprestasi dengan Keterampilan Mengajar", Jurnal Pendidikan dan Kebudayaan, 14.75, 2016.

Hildebrandt, Susan A., and Minhee Eom, "Teacher Professionalization: Motivational Factors and the Influence of Age", Teaching Teacher Education, 27.2, 2011.

Karweti, Engkay, "Pengaruh Kemampuan Manajerial Kepala Sekolah dan Faktor Yang Mempengaruhi Motivasi Kerja terhadap Kinerja Guru SLB di Kabupaten Subang", Jurnal Penelitian Pendidikan, 11.2, 2010.
König, Johannes, and Martin Rothland, "Motivations for Choosing Teaching as a Career: Effects on General Pedagogical Knowledge during Initial Teacher Education", Asia-Pacific Journal of Teacher Education, 40.3, 2012.

Lizzio, Alf, Neil Dempster, and Regan Neumann, "Pathways to Formal and Informal Student Leadership: The Influence of Peer and Teacher-Student Relationships and Level of School Identification on Students' Motivations", International Journal of Leadership in Education, 14.1, 2011.

Manuel, Jackie, and John Hughes, "'It Has Always Been My Dream': Exploring Pre-Service Teachers' Motivations for Choosing to Teach", Teacher Development, 10.1, 2006.

Ryan, Richard M., and Edward L. Deci, "Intrinsic and Extrinsic Motivations: Classic Definitions and New Directions", Contemporary Educational Psychology, 25.1, 2000.

Van Duzor, Andrea Gay, "Capitalizing on Teacher Expertise: Motivations for Contemplating Transfer from Professional Development to the Classroom", Journal of Science Education and Technology, 20.4, 2011.

Watt, Helen MG, and Paul W. Richardson, "Motivations, Perceptions, and Aspirations Concerning Teaching as a Career for Different Types of Beginning Teachers", Learning and Instruction, 18.5, 2008.

Werdayanti, Andaru, "Pengaruh Kompetensi Guru dalam Proses Belajar Mengajar di Kelas dan Fasilitas Guru Terhadap Motivasi Belajar Siswa", Dinamika Pendidikan, 3.1, 2008. 